\title{
STRATEGI BERTAHAN CAFE MELALUI PENDEKATAN INTEGRATED MARKETING COMMUNICATION DI MASA PANDEMI COVID-19
}

\author{
Jihan Indah Sari ${ }^{1^{*}}$ dan Joko Susilo \\ ${ }^{1,2}$ Universitas Muhammadiyah Malang, Malang, Indonesia \\ *jihanindah0812@gmail.com
}

\begin{abstract}
Covid-19 Pandemic affects all sectors around the world, including economic sector especially in culinary bussines field. The impact of covid-19 is felt directly by bingsoo cafe, such as income has dropped and there is no customer that comes by due to government's policy which forces people to stay at home. The purpose of this research is to describe the defensive strategy by bingsoo cafe through the approach of integrated marketing communications (IMC), so that it can continue to defense and adapt to the bussines situation of Covid-19 pandemic. The method of this research is qualitative with observation technique and deep interview. The result of this research indicates that bingsoo cafe applies the strategy of Integrated Marketing Communications (IMC) by combining 9 out of 12 elements of promotion. Those elements are Advertising, Social Media And Website/Internet Marketing, Personal Selling, Public Relations, Sales Promotion, Point Of Sale And Merchandising, Corporate Identity, Packaging, And Word Of Mouth.
\end{abstract}

Keywords: strategy, integrated marketing communication, covid-19, bingsoo cafe

\begin{abstract}
Abstrak
Pandemi Covid-19 yang melanda seluruh dunia tidak dipungkiri berdampak pada semua sektor kehidupan, salah satunya sektor ekonomi khususnya pada bidang usaha makanan dan minuman. Dampak dari wabah covid-19 dirasakan langsung oleh Cafe Bingsoo seperti penghasilan yang menurun drastis dan tidak ada pelanggan yang datang dikarenakan peraturan pemerintah yang mengharuskan seluruh masyarakat untuk tetap dirumah. Tujuan penelitian ini adalah mendeskripsikan apa saja strategi bertahan yang dilakukan oleh cafe bingsoo melalui pendekatan komunikasi pemasaran terpadu sehingga dapat terus bertahan dan beradaptasi dengan situasi bisnis di masa pandemi Covid-19. Metode penelitian yang digunakan adalah kualitatif dengan teknik observasi dan wawancara mendalam. Penelitian ini menunjukkan bahwa cafe bingsoo berhasil mempertahankan bisnisnya di masa pandemi covid-19, bahkan menuai kesuksesan kembali di masa new normal dengan menerapkan komunikasi pemasaran terpadu dengan mengkombinasikan 9 dari 12 elemen promosi yaitu periklanan, sosial media dan situs atau pemasaran internet, penjualan personal, hubungan masyarakat, promosi penjualan, titik penjualan barang dagangan, identitas perusahaan, pengemasan, dan pemasaran kata dari mulut.
\end{abstract}

Kata Kunci: strategi, komunikasi pemasaran terpadu, covid-19, cafe bingsoo

\section{PENDAHULUAN}

Covid-19 (Coronavirus Disease 2019) yang melanda seluruh dunia, tidak dipungkiri berdampak besar pada seluruh sektor kehidupan masyarakat khususnya di sektor ekonomi. Menurut International Monetary Fund (IMF), proyeksi ekonomi global akan tumbuh minus $3 \%$ di Indonesia, dimana memiliki dampak yang signifikan terhadap pariwisata, perdagangan, dan industri termasuk
Pelaku Usaha Mikro, Kecil dan Menengah (UMKM) (Hardilawati 2020). Covid-19 mewabah di Indonesia dikonfirmasi mulai dari Maret 2020 dan hingga penghujung tahun 2020 virus ini pun belum dapat diatasi. Adapun langkah-langkah yang dibuat oleh Pemerintah Indonesia untuk meminimalisir penularan Covid-19 yaitu dengan menerapkan Pembatasan Sosial Berskala Besar (PSBB), dan penerapan new normal. 
Saat PSBB diberlakukan dengan dikeluarkannya PP Nomor 21 tahun 2020, pemerintah mengharuskan kepada seluruh masyarakat agar tetap berada didalam rumah jika tidak ada keperluan mendesak diluar rumah. Dampaknya terlihat secara langsung dari Pemutusan Hubungan Kerja (PHK) besarbesaran yang dilakukan beberapa perusahaan, penutupan beberapa usaha, dan penghasilan pelaku usaha yang menurun drastis bahkan ada beberapa yang bangkrut dan tutup salah satunya usaha di bidang makanan dan minuman seperti cafe. Ketua Umum Asosiasi Pengusaha Kafe dan Restoran Indonesia (Apkrindo), Eddy Susanto yang mengatakan adanya penurunan pemasaran hingga 50\% dan Ketua Gabungan Pengusaha Makanan dan Minuman Indonesia (GAPMMI), Adhi S Luqman yang mengatakan pendapatan tempat makanan seperti restoran dan cafe turun 70 80\% (Firmansyah \& Wulandari 2020).

Adapun menurut survey yang dilakukan Rumah Zakat pada Juni 2020 terhadap 632 koresponden yang berasal dari 28 provinsi di Indonesia dengan jenis usaha meliputi usaha kuliner $52 \%$, jasa $14 \%$,agrobisnis $11 \%$, handycraft $6 \%$, dan fashion $5 \%$ menghasilkan pernyataan bahwa 9 dari 10 pelaku usaha mengalami penurunan rata- rata omzet atau penghasilan harian sebagai akibat dari wabah Covid-19. Bahkan, sebanyak $41 \%$ pelaku usaha tidak menghasilkan omzet sama sekali selama Covid-19. Adapun upaya menjaga hubungan baik dengan konsumen dilakukan oleh para pelaku usaha sebanyak $49 \%$ demi menjaga keberlangsungan usahanya (Amanda 2020).

Menurut Data dari kementerian koperasi dan Usaha Kecil Menengah (UKM), Indonesia terdapat 64.194.057 UMKM dan memperkerjakan 116.978.631 tenaga kerja pada tahun 2018 sehingga UMKM menjadi tulang punggung perekonomian nasional yang terdampak serius pada aspek produksi, pendapatan, dan jumlah tenaga kerja yang harus dikurangi karena pandemi ini (Pakpahan 2020). Situasi ini membuat UMKM dituntut untuk menyesuaikan diri dengan keadaan karena usaha yang mampu bertahan adalah usaha yang responsif dengan perkembangan zaman. Selain itu, UMKM dituntut juga dapat menyusun strategi untuk mengkomunikasikan produk atau jasanya dengan melakukan pemasaran yang berguna untuk mempertahankan usahanya serta meningkatkan penjualannya. Strategi pemasaran efektif yang secara luas telah digunakan perusahaan besar maupun kecil adalah strategi komunikasi pemasaran terpadu atau Integrated Marketing Communication (IMC). Dalam penelitian (Chrismardani 2014), IMC dilakukan oleh UMKM secara sederhana untuk mengkomunikasikan produknya kepada konsumen secara luas, program promosi ini pun secara reaktif dapat disusun sesuai dana yang dimiliki.

Selang beberapa bulan, Indonesia menerapkan New Normal berdasarkan Keputusan Menteri Kesehatan Nomor HK.01.07/MENKES/328/2020 tentang Panduan Pencegahan dan Pengendalian Covid19 di Tempat Kerja Perkantoran dan Industri dalam Mendukung Keberlangsungan Usaha pada Situasi Pandemi. New Normal memberikan kesempatan kepada usaha-usaha untuk membuka kembali tempat usahanya tetapi dengan sejumlah protokol kesehatan yang ketat. Disamping itu, situasi new normal ini tetap membatasi kegiatan masyarakat dan menghimbau agar tetap dirumah saja. Banyak masyarakat yang merasa bosan serta mengeluh menurunnya penghasilan untuk membiayai kehidupan. Masyarakat kini dituntut agar memprioritaskan kebutuhan pokok dan vitamin dibandingkan dengan membeli sesuatu yang diinginkan.

Dampak dari Covid-19 ini pun dirasakan langsung oleh salah satu UMKM di Malang di bidang makanan dan minuman yaitu cafe bingsoo. Cafe bingsoo yang terkenal dengan tagline nya yaitu "It's Korean Time" merupakan tempat yang menjual makanan dan minuman khas Korea Selatan. Adanya pandemi Covid-19 membuat cafe ini yang biasanya ramai pelanggan menjadi sangat sepi dan bahkan tidak ada pelanggan yang datang. 
Tentu hal ini berdampak pada penghasilan cafe yang menurun drastis sehingga terjadi pemangkasan jumlah karyawan untuk meminimalisir pengeluaran keuangan. Tetapi, memasuki era new normal, usaha ini dapat bangkit dan mengalami peningkatan penjualan. Cafe bingsoo berhasil bertahan dengan menerapkan strategi komunikasi pemasaran terpadu. Cafe bingsoo dipilih peneliti sebagai objek penelitian karena usaha ini merupakan UMKM yang notabenenya bukan menjual bahan-bahan pokok yang dibutuhkan masyarakat selama masa pandemi, sehingga kecil kemungkinan mendatangkan konsumen untuk membeli produk yang ditawarkan. Tetapi, cafe ini dapat bertahan hingga berhasil meningkatkan penjualannya. Penelitian ini menjadi menarik karena akan mengungkap seperti apa strategi IMC yang digunakan oleh Cafe Bingsoo sehingga dapat bertahan selama masa pandemi Covid-19, bahkan dapat menuai kesuksesan kembali di era new normal.

Dari uraian diatas, maka rumusan masalah dalam penelitian ini adalah bagaimana strategi yang digunakan oleh cafe bingsoo Malang untuk mempertahankan bisnisnya di tengah masa pandemi Covid-19 melalui pendekatan Integrated Marketing Communication. Tujuan penelitian adalah untuk mendeskripsikan apa saja strategi bertahan yang dilakukan oleh cafe bingsoo Malang melalui pendekatan integrated marketing communication sehingga dapat terus bertahan dan beradaptasi dengan situasi bisnis di masa pandemi Covid-19. Adapun manfaat dari penelitian ini diharapkan dapat memberikan sumbangan bagi perkembangan kajian ilmu komunikasi khususnya yang berkaitan dengan Integrated Marketing Communication di masa pandemi ini. Selain itu, secara praktis penelitian ini diharapkan dapat memberikan rekomendasi bagi para pelaku usaha lainnya dalam menerapkan strategi Integrated Marketing Communication di masa pandemi Covid-19.

Kerangka pokok pikiran yang digunakan dalam penelitian ini adalah strategi bertahan dan integrated marketing communication atau komunikasi pemasaran terpadu. Menurut Ahimsa (dalam Damis, 2018), strategi adalah hasil interpretasi manusia menggunakan kerangka pemikiran tertentu atas situasi yang dihadapi sehingga membentuk pola-pola usaha yang direncanakan untuk mencari solusi dari suatu masalah. Bertahan adalah kemampuan sistem, komunitas atau masyarakat terkena terhadap bahaya untuk menahan, menyerap, mengakomodasi, dan memulihkan dari efek bahaya secara tepat waktu dan cara efisien, termasuk melalui cara pelestarian dan pemulihan yang penting dasar struktur dan fungsi (Muller dalam Damis 2018).

Dari pernyataan diatas, singkatnya strategi bertahan merupakan pola-pola usaha yang digunakan agar mampu bertahan menghadapi suatu masalah yang dihadapi hingga dapat menyelesaikan permasalahan itu. Strategi bertahan diterapkan oleh perusahaan terkait erat dengan kemampuan bertahan perusahaan (Susilo et al dalam Susilo 2009). Kemampuan dalam bertahan lebih dimiliki usaha kecil dan menengah karena sifat bisnis dari UMKM yang langsung dikelola oleh para owner sehingga lebih fleksibel dalam beradaptasi dan mempunyai kecepatan dan tekad (Susilo 2009). Munculnya persaingan dan perubahan yang sangat cepat seperti teknologi, kebutuhan konsumen, siklus produk yang pendek adalah hal yang tidak dapat dihindari. Oleh karena itu, perusahaan harus mengerti dan memahami apa yang terjadi di pasar, apa yang diinginkan para konsumen, dan berbagai perubahan apa yang terjadi di lingkungan bisnisnya sehingga mampu bertahan dan bersaing dengan perusahaan lainnya. Dengan demikian, perusahaan dituntut untuk dapat memilih dan menetapkan strategi yang tepat untuk menghadapi persaingan dan mempertahankan eksistensinya.

Seperti yang diketahui, seluruh bisnis di dunia kini dihadapkan dengan suatu permasalahan yaitu adanya wabah Covid-19. Dalam penelitian (Hardilawati 2020), terdapat beberapa strategi bertahan yang dapat dilakukan oleh UMKM yaitu dengan memanfaatkan penjualan e-commerce, 
perbaikan kualitas produk dan layanan, Customer Relationship Marketing, dan pemilihan strategi pemasaran dengan meningkatkan fokus pada Digital Marketing. Adapun strategi pemasaran yang terkenal banyak digunakan oleh berbagai perusahaan baik besar maupun kecil adalah Integrated Marketing Communication (IMC) atau komunikasi pemasaran terpadu.

IMC pada dasarnya adalah proses perencanaan dan pengembangan secara sistematis untuk menentukan pesan yang paling efektif dan konsisten yang bertujuan membantu kegiatan pemasaran sehingga dapat menyasar target audiens yang sesuai. Pemasaran memfasilitasi kegiatan pertukaran dan pengembangan hubungan dengan konsumen dengan mencermati kebutuhan dan keinginan konsumen yang selanjutnya dikembangkan dengan membuat suatu produk (product) dan menawarkannya pada harga (price) tertentu, serta dipasarkan pada tempat (place) bagi produknya, kemudian dilakukan kegiatan promosi (promotion) guna menarik konsumen pada produk bersangkutan.

Integrated Marketing Communication mempunyai berbagai definisi dari beberapa ahli. Menurut Don E. Scultz (dalam Prasetyo et al. 2018), IMC merupakan proses pengembangan dan penerapan bentuk- bentuk komunikasi persuasif kepada pelanggan dan calon pelanggan secara berkelanjutan yang bertujuan memberikan efek langsung kepada perilaku khalayak sasaran yang dimilikinya. Dalam hal ini IMC menganggap semua sumber yang dapat menciptakan hubungan pelanggan atau calon pelanggan dengan produk atau jasa dari suatu merek merupakan peluang yang baik untuk menyampaikan pesan. Sedangkan, IMC menurut American Association of Advertising Agencies (dalam Prasetyo et al. 2018), merupakan suatu konsep perencanaan komunikasi pemasaran yang memberikan nilai tambah dari suatu rencana yang menyeluruh. Rencana tersebut mengevaluasi peran strategis dari macammacam ilmu komunikasi dan menggabungkannya dengan bidang lain agar membuahkan suatu hasil yang akurat, konsisten, dan efek maksimum melalui penyatuan pesan-pesan yang terpisah. Sementara itu, menurut PR Smith dan Ze Zook (2011), IMC adalah bentuk dari komunikasi pemasaran yang terpadu dalam sebuah organisasi. Semua organisasi modern baik perusahaan bisnis maupun nirlaba, menggunakan berbagai bentuk komunikasi pemasaran untuk mempromosikan produk atau jasa yang ditawarkannya dan mencapai tujuan finansial dan nonfinansial (Smith and Zook 2011).

IMC mencakup usaha koordinasi berbagai elemen bauran promosi (Promotion Mix) atau disebut juga bauran komunikasi pemasaran (Marketing Communication Mix). PR Smith dan Ze Zook (2011) menyebutkan bauran promosi tersebut sebagai alat komunikasi yang terdiri dari advertising, direct marketing, social media and website/internet marketing, sales promotion, public relations, personal selling, sponsorship, exhibition, point of sale and merchandising, corporate identity, packaging, dan word of mouth.

Pertama, Advertising. Segala bentuk komunikasi nonpersonal yang melibatkan media massa mengenai informasi perusahaan, produk, jasa, atau ide yang dibayar oleh sponsor (Morissan 2010). Iklan juga efektif dalam menciptakan brand image dalam benak konsumen. Tetapi, karena sifatnya yang nonpersonal, maka feedback dari konsumen tidak didapatkan dengan cepat. Terdapat beberapa media yang biasa dijadikan sarana beriklan yaitu media massa seperti televisi, koran, radio, dan majalah. Ada pun sosial media seperti twitter, facebook, dan instagram.

Kedua, Direct Marketing. Cara perusahaan untuk melakukan komunikasi langsung dengan konsumen. Elemen ini cukup banyak digunakan oleh perusahaan karena menimbulkan feedback yang cepat terhadap transaksi penjualan (Morissan 2010). Pemasaran langsung dilakukan dengan mengirim pesan melalui email, sms, dan/atau WhatsApp, telemarketing, dan penjualan langsung kepada target konsumen. Cara ini 
memerlukan pengelolaan database konsumen untuk melancarkan promosinya.

Ketiga, Social Media and Website/Internet Marketing. Pemasaran melalui media interaktif yang utamanya adalah internet dikarenakan kemajuan teknologi komunikasi. Media interaktif memungkinkan komunikasi dua arah sehingga antara penjual dan pembeli dapat berinteraksi secara real time seperti mengajukan dan menjawab pertanyaan serta melakukan pembelian (Morissan 2010). Internet menjadi media utama promosi yang berorientasi konsumen seperti pemberian kupon online, undian, dan kontes berhadiah di sosial media dan website (Shimp 2004).

Keempat, Sales Promotion. Aktivitas yang berguna memberikan nilai tambah kepada tenaga penjualan, distributor, atau konsumen untuk meningkatkan penjualan contohnya seperti pemberian potongan harga (Morissan 2010). Elemen ini efektif menarik calon pelanggan untuk mencoba membeli produk untuk pertama kalinya. Tetapi, keuntungan penjualan dari elemen ini biasanya dalam jangka pendek.

Kelima, Public Relations. Upaya mengkomunikasikan dan melakukan sesuatu yang baik untuk menciptakan citra positif perusahaan di masyarakat. Bila suatu perusahaan bisa mendapatkan hati dimasyarakat, maka konsumen dengan senang hati memilih perusahaan itu. Menurut Dominick (dalam Morissan 2010), humas memiliki kaitan erat dengan opini publik, dimana humas harus pintar dalam membaca keadaan dimasyarakat sehingga strategi yang dilakukan harus bisa mempengaruhi publik untuk memberikan opini positif bagi suatu perusahaan. Humas juga melakukan fungsi manajemen untuk menetapkan tujuan yang ingin dicapai dengan menyesuaikan situasi yang ada, lalu memberikan saran secara rutin kepada manajemen mengenai apa yang harus dilakukan. Selain itu, humas juga mempublikasikan berita mengenai perusahaan di media massa atau online. Hal ini menjadi penting untuk menyebarkan sesuatu mengenai perusahaan kepada khalayak yang lebih luas.
Keenam, Personal Selling. Penjualan secara langsung yang dilakukan antar personal dimana penjual langsung berinteraksi pada calon pembelinya. Penjual dapat berusaha untuk mempengaruhi calon pembeli untuk membeli produknya dan pembeli bisa langsung melihat dan mendengarkan respon pembeli. Dalam interaksi itu pun, penjual bisa membantu menjelaskan produk yang ditanyakan calon pembeli serta memberikan rekomendasi sesuai dengan kebutuhan atau keinginan pembeli. Feedback yang didapatkan dari elemen ini dirasakan langsung dan lebih tepat karena presentasi penjualan dapat dinilai langsung dari respon pembeli.

Ketujuh, Sponsorship. Suatu kegiatan yang dilakukan perusahaan dengan memberikan dukungan dana pada penyelenggaraan event. Selain dana, sponsorship juga bisa berupa barang atau sesuatu yang disewakan sesuai kesepakatan negosiasi. Pihak penerima dukungan dana harus memberikan timbal balik komersial untuk publisitas dan asosiasi merek. Sponsorship terdiri dari program kegiatan, tujuan, ahli yang dibutuhkan terkait dengan tingkat kepuasan manajemen (Smith and Zook 2011).

Kedelapan, Exhibition. Suatu acara yang ditujukan untuk memperlihatkan kepada publik disuatu tempat tertentu mengenai produk atau jasa. Pameran menyatukan kelompok produsen, distributor, dan jasa yang terkait dalam satu lokasi yang dirancang khusus untuk industri khusus. Pameran dapat memberi efek maksimal dengan mengintegrasikan bentuk komunikasi korporat secara berjangka panjang (Smith and Zook 2011). Adapun keuntungan dari pameran adalah meningkatkan market share, mendapatkan banyak prospek, dan bahkan meningkatkan penjualan.

Kesembilan, Point of Sale and Merchandising. Bentuk promosi khusus dengan men-display produk untuk menarik perhatian pelanggan. Biasanya display ditempatkan dekat dengan meja kasir atau juga bisa didepan tempat penjualan. Adapun promosi ini juga berupa pemberian barang 
secara cuma-cuma kepada pelanggan yang membeli produk tertentu sehingga dapat membuat pelanggan tertarik untuk membeli produk itu.

Kesepuluh, Corporate Identity. Identitas perusahaan adalah kepribadian dari suatu perusahaan atau organisasi yang merupakan pembeda antara satu perusahaan dengan perusahaan lainnya. Identitas dirancang untuk memfasilitasi pencapaian tujuan bisnis perusahaan, biasanya diwujudkan dengan branding dan penggunaan merek dagang. Identitas ini termasuk nama perusahaan, logo, slogan, bangunan, dekorasi, seragam, warna perusahaan, bahkan penampilan fisik karyawan yang berhadapan dengan pelanggan. Pada intinya, dengan adanya identitas perusahaan tersebut membuat masyarakat mengetahui, mengenal, merasakan, dan memahami filosofi dari perusahaan tersebut.

Kesebelas, Packaging. Kegiatan dalam mendesain dan membuat kemasan suatu produk. Elemen promosi ini menjadi penting karena seringkali konsumen tidak terlalu minat dengan produknya, tetapi membeli produk tersebut karena senang dengan bentuk atau desain dari kemasannya. Pada intinya, pengemasan dilakukan agar konsumen tertarik membeli karena terdapat nilai plus dari kemasan produk tersebut menurut konsumen itu.

Keduabelas, Word of Mouth. Pembicaraan asli dari satu konsumen kepada konsumen lainnya mengenai suatu produk atau jasa sehingga secara tidak langsung konsumen itu melakukan promosi bagi produk atau jasa tersebut. Word of mouth timbul karena keunggulan produk atau jasa serta membuat konsumen senang. Elemen promosi yang sering disebut viral marketing ini memiliki tingkat kepercayaan yang tinggi daripada iklan komersial dikarenakan informasi dan rekomendasi yang diberikan konsumen jujur dari pengalamannya setelah menggunakan suatu produk atau jasa sehingga dapat mempengaruhi keputusan pembelian konsumen lainnya. WoM menjadi cara efektif yang dapat diukur dengan cara banyaknya publik yang menandai, memposting, dan membagikan ulang postingan (repost) konten yang dibuat oleh perusahaan, sehingga dapat membangun awareness masyarakat umum yang sebelumnya tidak tahu mengenai produk atau jasa suatu perusahaan. (Karimah, Saputra, and Wahyuningratna 2020).

IMC memang terkesan fokus pada promosi, tetapi perlu diingat bahwa IMC bukan sekedar mempromosikan produk atau jasa, melainkan juga merupakan usaha untuk memperkuat citra merek, meyakinkan pelanggan atau calon pelanggan untuk memilih suatu merek dan akhirnya membuat pelanggan menjadi setia pada suatu merek tersebut. Dengan kata lain, IMC membantu sebuah perusahaan untuk menyasar pangsa pasar yang efektif secara berkelanjutan. Selain itu, IMC yang dilakukan dapat menghasilkan konsistensi komunikasi yang lebih baik, anggaran komunikasi yang lebih efektif, dan dampak penjualan yang lebih besar. Terlebih di masa pandemi ini, pelaku usaha harus mampu menggabungkan kekuatan online maupun offline marketing demi keberlangsungan usahanya.

Penelitian mengenai Integrated Marketing Communication sudah sering kali dilakukan oleh beberapa peneliti. Tetapi penelitian tersebut dilakukan sebelum adanya pandemi Covid-19. Beberapa penelitian terdahulu mengenai strategi komunikasi pemasaran terpadu yang digunakan oleh cafe diantaranya terdapat penelitian dari Mustiar Hasri (2016) tentang strategi komunikasi pemasaran terpadu yang diterapkan oleh re caffe platinum pekanbaru dalam meningkatkan pelanggan. Penelitian mendeskripsikan strategi IMC yang dilakukan melalui iklan, promosi penjualan, pensponsoran, pengemasan, serta sosial media dan situs. Kedua, penelitian dari Dwi Prastyo (2018) tentang komunikasi pemasaran terpadu omah nenek cafe dalam upaya meningkatkan jumlah konsumen. Penelitian mendeskripsikan strategi IMC melalui periklanan, promosi penjualan, pemasaran langsung, hubungan masyarakat, dan penjualan personal. Keduanya memiliki tujuan yang sama yaitu meningkatkan jumlah pelanggan atau 
konsumen. Lalu penelitian yang dilakukan saat pandemi Covid-19 dilakukan oleh Wan Laura Hardilawati (2020) tentang strategi bertahan UMKM di tengah pandemi covid-19. Penelitian memaparkan strategi bertahan yang efektif dilakukan secara umum oleh UMKM yaitu e-commerce, digital marketing, perbaikan kualitas produk dan layanan, dan customer relationship marketing.

Dengan beberapa penelitian tersebut, maka penelitian ini dilakukan sebagai perbandingan tentang strategi komunikasi pemasaran terpadu pada UMKM khususnya cafe. Perbedaan dengan penelitian sebelumnya ada pada objeknya yaitu cafe bingsoo Malang yang belum pernah diteliti sebelumnya. Variabel yang difokuskan pada analisis juga terdapat perbedaan, khususnya pada elemen promosi. Situasi pandemi Covid-19 juga menjadi suatu pembaruan dalam penelitian ini.

\section{METODOLOGI PENELITIAN}

Penelitian ini menggunakan paradigma naturalisme, dimana peneliti mengungkap fakta sesuai dengan kejadian yang sebenarnya. Pendekatan penelitian yang digunakan adalah kualitatif, dengan tipe penelitian menggunakan deskriptif kualitatif yaitu menggambarkan peristiwa yang terjadi apa adanya tanpa ada rekayasa serta mencatat hasil data secara terperinci dan dasar penelitian menggunakan studi kasus yaitu mencari masalah dari satu kasus untuk mendapatkan gambaran secara menyeluruh dan mendalam (Machmud 2018).

Penelitian dilakukan pada bulan Maret Desember 2020. Pengumpulan data dilakukan dengan teknik observasi di Cafe Bingsoo di Jalan Songgoriti No 1, Kecamatan Lowokwaru, Kota Malang, Jawa Timur. Selain itu, ada pun cara pengumpulan data lainnya menggunakan wawancara mendalam dengan subyek penelitian diantaranya owner, manajer pemasaran, dan karyawan.

Data-data yang telah dikumpulkan akan dianalisis menggunakan tiga langkah yaitu melalui kondensasi data, penyajian data, dan penarikan kesimpulan. Selanjutnya, setelah data dianalisis maka data diuji keabsahan datanya. Peneliti akan menggunakan teknik triangulasi sumber, yaitu menguji kebenaran fakta yang diperoleh dengan mewawancarai sumber yang berbeda. Hal ini dilakukan karena perlu adanya pembanding antara satu sumber dengan yang lainnya, sehingga data yang didapatkan lebih teruji keabsahannya.

\section{HASIL DAN PEMBAHASAN}

Cafe Bingsoo dihadapkan dengan situasi sulit pada masa awal pandemi di Indonesia. Cafe yang sudah berdiri selama 6 tahun ini terlihat sepi bahkan tidak ada pelanggan yang datang. Terlebih saat diberlakukannya PSBB yang mengharuskan setiap orang beraktivitas di dalam rumah untuk meminimalisir penularan virus. Seluruh masyarakat lebih hati-hati dalam memilih makanan untuk dikonsumsi karena khawatir tertular virus. Alhasil, banyak masyarakat yang memilih untuk memasak sendiri dirumah.

Usaha ini pun memutar otak agar dapat bertahan dan tidak gulung tikar. Langkah awal yang di ambil cafe bingsoo pada tanggal 24 Maret 2020 dengan melakukan pemangkasan seluruh karyawan paruh waktu dikarenakan penghasilan yang menurun dratis. Pada April dan Mei, bingsoo berada di masa-masa kritis. Pendapatan sangat turun dan pengeluaran lebih besar. Jam kerja karyawan pun dipotong untuk menghemat pengeluaran. Tetapi, pada bulan Juni saat diberlakukannya new normal, Bingsoo mulai bangkit kembali ditandai dengan kenaikan pendapatan pada bulan Juni sebanyak $70 \%$ dari bulan sebelumnya. Bulan berikutnya, bingsoo terlihat makin ramai sehingga karyawan yang ada sebanyak 6 orang pun kewalahan sehingga direkrut dua orang karyawan dibagian kasir. Di bulan Agustus, pendapatan bingsoo meningkat drastis yang awalnya 55 juta di bulan Juli menjadi 80 Juta di bulan Agustus. Akhirnya, bingsoo memutuskan untuk merekrut 2 orang lagi di bagian minuman dan makanan agar penjualan bisa berjalan lancar.

Berdasarkan hasil wawancara dan pengamatan, peneliti melihat bahwa cafe bingsoo menerapkan beberapa strategi IMC 
untuk bertahan di masa pandemi. Pertama. Advertising. Bingsoo kerap memakai jasa iklan yang disediakan oleh instagram untuk mempromosikan produknya. Bingsoo melakukan iklan maksimal 3 kali dalam sebulan. Biaya yang dikeluarkan untuk sekali iklan berkisar Rp 50.000 - 100.000.

Kedua, Social Media and Website/Internet Marketing. Bingsoo memfokuskan internet marketing nya pada sosial media instagram. Akun instagram Bingsoo dengan nama @ bingsoomlg memiliki pengikut sejumlah 13 ribu. Bingsoo meng-upload postingan maksimal 3 kali dalam seminggu pada jam sekitar 12.00-14.00 dan 18.30-20.00. Kontennya adalah seputar visual menu, suasana cafe, informasi diskon, tips menghindari Covid-19, ucapan hari besar nasional, dan giveaway. Kemudian untuk cerita di instagram, bingsoo membuat 5-8 cerita setiap harinya. Bingsoo tidak pernah melewatkan untuk membagikan ulang story berupa gambar atau video para pelanggannya yang menandai akun bingsoo di instagram.

Selain itu, cafe bingsoo membuat giveaway di Instagram dengan memberikan kuis mengenai makanan yang terdapat dalam scene salah satu drama Korea yang sedang tayang pada bulan Desember yaitu Tale of The Nine Tailed. Pemilihan drama tersebut disesuaikan dengan tujuan bingsoo untuk memasarkan menu baru yaitu dakbal (ceker pedas Korea). Bingsoo memberikan hadiah gratis dakbal dan es teh bagi 9 orang pemenang yang dapat menebak episode dari scene 2 pemeran utama Tale of The Nine Tailed saat memakan dakbal. Kuis dilaksanakan selama satu minggu mulai dari 5-11 desember 2020. Peserta menjawab kuis dengan membagikan ulang postingan kuis di instagram story masing-masing dan menandai akun bingsoo serta 3 teman peserta. Setiap peserta juga wajib follow akun instagram bingsoo.

Disamping fokus pada sosial media, bingsoo juga mengandalkan e-commerce, gojek dan grab yang mempunyai layanan pesan antar makanan yaitu gofood dan grabfood. Bingsoo aktif membuat promo di kedua platform online tersebut dan membagikannya pada postingan dan story di akun instagram bingsoo. Pada bulan April hingga Mei 2020 pendapatan bingsoo didominasi dari kedua e-commerce tersebut. Keduanya memberikan pemasukan sebanyak $69 \%$ di bulan April dan $72 \%$ di bulan Mei, dimana pada bulan tersebut bingsoo memiliki pendapatan yang sedikit.

Ketiga, Sales Promotion. Selama masa pandemi bingsoo aktif dalam membuat promosi yang disediakan berupa paket, diantaranya paket hemat (pahe) dirumah aja, pahe new normal, paket combo bingsoo ramerame, dan paket hematlicious. Paket tersebut memiliki potongan harga yang berbeda mulai dari $20 \%$ - 30\%. Paket dibuat berdasarkan kombinasi makanan atau minuman yang paling banyak dan sedikit terjual, seperti paket hematlicious 1 yaitu kimbab dan strawberry tea. Kimbab adalah makanan yang laris dibeli sedangkan strawberry tea adalah minuman yang jarang dibeli. Dari semua paket promosi yang ada, pahe dirumah aja 4 atau paket new normal 4 (patbingsu dan teokbokki) yang paling banyak dipesan oleh konsumen dengan potongan harga sejumlah $20 \%$. Paket promosi dikhususkan untuk penjualan melalui $e$ commerce yaitu gojek dan grab.

Selain itu, bingsoo membuat diskon $50 \%$ makan ditempat khusus varian bingsu dan minuman saat perayaan ulang tahunnya yang ke 6 pada tanggal 18 desember 2020. Tidak lupa, bingsoo menerapkan protokol kesehatan saat promosi berlangsung dengan memastikan setiap pelanggan yang datang untuk mencuci tangan, memakai masker, dan menjaga jarak dikarenakan situasi pandemi. Penjualan pun meningkat drastis pada hari itu mencapai 5,7 juta dikarenakan konsumen yang datang tidak hanya membeli menu yang diskon saja, tetapi turut membeli menu lainnya.

Keempat, Public Relations. Bingsoo melakukan aktivitas PR dengan memberikan bantuan Sembilan Bahan Pokok (Sembako) dan hand sanitizer kepada beberapa masyarakat terdampak Covid-19 di Kabupaten Malang pada tanggal 29 September 2020. 
Penerapan strategi humas juga terlihat dengan pelayanan yang baik dan ramah kepada seluruh pelanggannya. Karyawan bingsoo terlihat melayani dengan baik permintaan dari pelanggannya baik online maupun offline. Bingsoo juga memastikan untuk langsung membersihkan meja setiap pelanggan meninggalkan bingsoo dan menyediakan hand sanitizer di pintu masuk dan di kasir.

Kelima, Personal Selling. Bingsoo memperkerjakan dua orang perempuan dibagian kasir khusus pada hari sabtu dan minggu secara shift. Karyawan di bagian kasir diminta untuk menawarkan menu makanan tertentu di hari sabtu dan minggu dengan diskon 50\%. Menu yang dipromosikan disesuaikan dengan situasi saat itu, contohnya saat viral drama Korea Selatan Start Up yang menayangkan makanan Corndog, maka menu itulah yang akan dipromosikan. Menu yang kurang diminati juga menjadi salah satu menu yang dipromosikan agar dapat terjual.

Seluruh karyawan terlihat fasih dalam menjelaskan setiap menu yang ditanyakan oleh pelanggan. Karyawan bingsoo juga memberikan rekomendasi menu yang sesuai dengan keinginan pelanggannya.

Keenam, Point of Sale and Merchandising. Bingsoo menempatkan bahan-bahan bingsu yaitu buah-buahan segar yang telah dipotong di samping meja kasir. Setiap kali konsumen memasuki bingsoo, pasti melihat jajaran buahbuahan segar dan juga bisa melihat langsung pembuatan bingsu.

Ketujuh, Corporate Identity. Bingsoo lebih menguatkan identitasnya melalui buku menu barunya. Pada menu bingsoo lama, logo ditempatkan dibagian kiri atas, sedikit visual menu, dan sedikit tulisan korea. Kemudian, pada menu barunya logo berwarna emas ditempatkan dibagian tengah depan cover, setiap menunya diberikan tulisan Korea dan visual makanan serta minuman yang menarik.

Kedelapan, Packaging. Bingsoo mengganti bahan kemasan untuk menu bingsu yang awalnya terbuat dari paper bowl menjadi plastik. Plastik dipilih karena lebih tahan air dan tidak mudah bocor.
Kesembilan, Word of Mouth. Bingsoo menciptakan word of mouth dengan memperhatikan 3 hal. Pertama, be interesting. Bingsoo menawarkan varian bingsu yang lebih beragam daripada pesaingnya Adapun varian bingsu nya yaitu Patbingsu, Bingo Bingsu, Oreo Bingsu, dan Rainbow Bingsu. Selain itu, untuk menarik perhatian konsumen, bingsoo merenovasi bagian outdoor cafenya menjadi lebih aesthetic dengan mengganti rumput biasa menjadi rumput sintetis, penambahan tanaman hias, serta mural yang lucu sehingga lebih instagramable. Bingsoo membagikan foto hasil renovasinya di akun resmi instagram bingsoo.

Kedua, make people happy. Bingsoo memastikan untuk menghidangkan pesanan pelanggan ke meja maksimal 15 menit. Bingsoo juga menempatkan kelinci di bagian outdoor dan ikan cupang hias di bagian indoor untuk menemani para pelanggan. Adanya kelinci dan ikan bertujuan sebagai penghibur pelanggan disela menunggu pesanan. Terlihat pelanggan senang bermain dengan kelinci dan melihat ikan cupang yang ada disisi ruangan, bahkan ada pelanggan yang datang dengan terang-terangan menanyakan keberadaan kelinci tersebut karena diberitahu oleh temannya.

Ketiga, earn trust and respect. Bingsoo memastikan setiap produknya higienis dan cafenya pun selalu bersih. Setiap karyawan diwajibkan untuk memakai masker dan sarung tangan saat membuat pesanan.

Berdasarkan hasil observasi dan wawancara, bingsoo mengerahkan berbagai usaha untuk dapat bertahan di masa pandemi ini dengan menggunakan IMC. Bingsoo lebih fokus pada pemasaran melalui internet atau media online karena tidak dipungkiri internet menjadi kebutuhan utama seluruh masyarakat di masa pandemi ini dikarenakan kegiatan yang banyak mengharuskan online dirumah saja seperti bekerja dan bersekolah. Menurut survei yang dilakukan Alvara Research Center, rata-rata penggunaan internet dalam sehari adalah 7-10 jam dan menunjukkan pula pengeluaran belanja masyarakat atas 
kebutuhan internet naik dari tahun lalu sebesar 6,1 persen hingga mencapai angka 8,1 persen (Rochim 2020). Media online juga dirasa tepat untuk digunakan oleh pelaku usaha karena efek penggunaan bauran promosi seperti periklanan, sales promotion, WoM, dan public relations dapat diukur dengan cepat. Fitur-fitur yang disediakan oleh media online membuat pelaku usaha dapat mengemas alat pemasarannya seefektif mungkin kepada konsumen (Pasaribu 2020).

Bingsoo lebih memilih instagram sebagai sosial media pemasarannya. Instagram menjadi media sosial yang banyak diminati dan digunakan pelaku usaha maupun konsumen. Selain itu, instagram sangat mudah diakses, diaplikasikan, dan dikomunikasikan dengan strategis. Instagram menawarkan jasa iklan dengan harga yang dapat disesuaikan dengan budget pengiklan. Iklan di sosial media seperti instagram dirasa lebih efektif karena kecenderungan masyarakat yang kini beralih ke platform online semasa pandemi. Terlebih lagi, dana yang dikeluarkan tidak sebanyak jika harus beriklan di televisi atau pun media massa lainnya. Iklan di instagram pun sangat membantu dalam mendapatkan target yang sesuai dan luasan pasarannya. Hal tersebut membawa kemajuan untuk kunjungan profil sehingga semakin banyak orang yang akan mengetahui mengenai suatu brand, walaupun belum tentu adanya aksi pembelian (Pasaribu 2020). Tetapi perlu diingat, Sama halnya dengan konsumen yang risih jika diikuti terus menerus oleh SPG (Sales Promotion Girl) / SPB (Sales Promotion Boy) saat melihat-lihat suatu produk di supermarket atau mall, konsumen juga akan risih jika media online terus memunculkan iklan untuk dikunjungi. Oleh karena itu, pelaku usaha harus pandai mengatur waktu beriklan dan memahami kebutuhan konsumennya. Dengan melakukan berbagai bentuk promosi di instagram, membuat konsumen tidak gampang jenuh bahkan mengundang ketertarikan konsumen itu sendiri. Menurut Prasetya (dalam Santoso 2018), ada bentuk-bentuk promosi yang dilakukan melalui media instagram untuk menciptakan hubungan antara brand dengan audiensnya diantaranya: voucher, iklan, diskon, kontes/lomba berhadiah, video menarik, event terbaru, artis endorse, repost gambar/video follower, dan menampilkan kutipan yang bernilai positif.

Keuntungan penggunaan instagram dilihat dari fitur insight yang menyediakan survei pengunjung dan aktivitas follower, sehingga mempermudah pelaku usaha dalam menembak target pesan pemasaran. Pemilihan waktu yang tepat juga diperlukan saat menggunakan media sosial agar promosi yang dilakukan dapat berjalan efektif. Contohnya bingsoo yang mengupload di jam sekitar 12.00-14.00 dan 18.30-20.00 karena biasanya jam tersebut adalah waktu istirahat yang biasa digunakan konsumen bingsoo untuk membuka media sosialnya. Siang hari juga biasanya terasa panas sehingga jika bingsoo mengupload konten mengenai menu utamanya dan dilihat oleh para konsumen akan menjadi stimulus konsumen untuk melakukan pembelian. Pelaku usaha harus paham mengenai perilaku konsumennya untuk dapat mengatur waktu yang tepat dalam melakukan pesan pemasaran (Pasaribu 2020).

Keadaan di masa pandemi juga membuat Bingsoo menaruh perhatian lebih pada $e$ commerce, yaitu gojek dan grab yang mempunyai layanan pesan antar makanan yaitu gofood dan grabfood. Menurut Laudon $\&$ Traver (dalam Hardilawati 2020) $e$ commerce adalah suatu proses membeli dan menjual produk secara elektronik dengan harga yang transparan, kemudahan akses, pasar global dengan perdagangan yang sangat efisien. Data dari McKinsey yang dimuat oleh suara.com menyatakan bahwa $34 \%$ konsumen menjadi lebih sering memesan makanan secara online dan $84 \%$ konsumen mengaku berniat untuk tetap memesan makan secara online pasca pandemi (Gunadha and Djailani 2020). Pihak ketiga ini memberikan kemudahan bagi penjual untuk memasarkan produknya dan pembeli untuk langsung memesan makanan tanpa harus datang ketempat penjual. Peran pelaku usaha sangat penting disini, pelaku 
usaha harus memilih visual seperti apa yang akan ditaruh pada aplikasi, deskripsi seperti apa yang cocok untuk menjelaskan produknya karena hal tersebut akan mempengaruhi keputusan pembelian konsumen.

Tidak kalah penting, pelaku usaha harus peka melihat situasi yang terjadi karena situasi atau keadaan yang sedang viral bisa menjadi kesempatan emas pelaku usaha dalam melancarkan pemasarannya. Contohnya, bingsoo membuat giveaway dengan memanfaatkan situasi dimana masyarakat senang menonton drama Korea selama masa pandemi. Didukung juga dari hasil penelitian Lembaga Ilmu Pengetahuan Indonesia (LIPI) menunjukkan 842 dari 924 responden menonton drama korea selama masa pandemi. 41,3\% menonton lebih dari 6 kali dalam seminggu, 28,4\% sebanyak 4-6 kali, dan 30,3 $\%$ sebanyak 1-3 kali (Pusparisa 2020). Seperti yang diketahui, dalam drama Korea terdapat scene yang menayangkan pemerannya menikmati makanan dan minuman khas Korea Selatan. Strategi ini efektif dalam membangun kesadaran masyarakat mengenai suatu brand. Terlebih, setiap peserta diharuskan untuk follow dan mention akun instagram. Konsumen juga akan merasa dekat dengan suatu brand karena menyuguhkan sesuatu yang diketahui dan disenangi oleh konsumennya.

Promosi berupa diskon atau potongan harga masih menjadi andalan dari setiap pelaku usaha untuk meningkatkan hasil penjualan. Potongan harga sebesar apapun itu persenan nya tetap akan mendapatkan tempat di hati para konsumen. Potongan harga bisa disematkan pada produk yang ingin ditingkatkan penjualannya, produk yang memasuki masa expired, pengenalan produk baru, dan juga pada hari-hari tertentu seperti ulang tahun suatu brand. Oleh karena itu, pelaku usaha harus pandai dalam menentukan strategi produk apa yang akan diberi potonan harga, kenapa potongan harga diberikan pada suatu produk, dan kapan potongan harga dilakukan.

Selain diskon, membuat paket promosi juga bisa dilakukan untuk memandu konsumen dalam memilih apa yang akan dibelinya. Paket bisa berupa perpaduan produk bestseller dan produk yang kurang diminati. Penamaan paket juga menjadi penentu untuk menarik perhatian konsumen.

- Selanjutnya, mengenai aktivitas humas dalam menentukan citra perusahaan. Banyak perusahaan berlomba-lomba untuk mendapatkan simpati dari masyarakat di masa pandemi seperti bingsoo yang memberikan bantuan saat Indonesia menjadi negara dengan peringkat 9 dengan kasus Covid-19 tertinggi di Asia (Septiani 2020). Pemberian bantuan di masa pandemi menjadi salah satu strategi yang menciptakan citra dan opini positif di masyarakat bahwa bingsoo peduli dengan keadaan Indonesia yang memprihatinkan.

Kualitas produk dan perbaikan layanan terutama kebersihan sangat perlu diperhatikan di masa pandemi ini. Aktivitas tersebut dilakukan demi memuaskan konsumen sehingga dapat membangun hubungan baik dengan konsumennya serta terciptanya persepsi positif mengenai suatu brand di masyarakat. Citra positif dan hubungan baik yang tercipta tentu dapat mendukung bentuk promosi lainnya sehingga tujuan dari perusahaan dapat lebih mudah tercapai (Prastyo 2018).

Penjualan personal yang dilakukan bingsoo ditawarkan langsung oleh karyawan kepada pelanggan yang datang dengan harapan pelanggan yang awalnya tidak tertarik dengan menu tertentu menjadi tertarik untuk mencoba membeli karena adanya penawaran khusus secara personal.

Sudah umum saat kita melihat produkproduk baru dan diskon dipajang didepan suatu toko. Penempatan itu bukan tanpa alasan, produk ditempatkan pada titik-titik tertentu yang bisa dengan mudah dilihat oleh konsumen agar konsumen yang awalnya tidak tau bahkan tidak ada niat membeli akan menjadi berfikir untuk membelinya karena visual dan penawaran yang menarik. Penempatan produk ditempat-tempat yang menjadi fokus penglihatan utama dari konsumen efektif dalam menarik perhatian 
konsumen seperti disamping pintu masuk dan disamping kasir saat konsumen akan membayar. Titik-titik penempatan yang tepat akan berdampak pada tingkat penjualan suatu produk itu pula.

Istilah konsumen/pembeli adalah raja sepertinya tepat karena setiap pelaku usaha akan melakukan apa saja dalam memuaskan para konsumennya. Bagaimana konsumen senang dan loyal pada suatu brand hingga dengan sendirinya merekomendasikan pada orang lain. Kegiatan tersebut dikenal dengan word of mouth. Tidak dipungkiri, komentar serta rekomendasi dari pelanggan yang membuat bisnis dapat bertahan melawan persaingan pasar dan juga perubahan iklim bisnis. Oleh karena itu, kualitas bahan dari produk, kebersihan dan keindahan serta kenyamanan tempat menjadi suatu yang harus terus dijaga pelaku usaha.

Bingsoo dikenal masyarakat dengan cafe makanan dan minuman khas Korea. Identitas ini harus terus ditanamkan pada konsumennya agar setiap orang yang ingin membeli makanan dan minuman khas Korea akan mengingat bingsoo. Penguatan identitas dilakukan bingsoo terlihat pada bentuk menu barunya. Pada menu baru ini kesan Korea lebih terasa serta lebih jelas bentuk dari setiap menunya. Selain penguatan identitas, bentuk menu baru itupun juga membantu pelanggan untuk memilih menu yang akan dipesannya karena terdapat penjelasan mengenai setiap menu dan bahan makanannya.

Packaging juga turut mempengaruhi keputusan pembelian. Penggantian kemasan dilakukan bingsoo karena melihat kecenderungan masyarakat yang lebih memilih memesan untuk dibawa pulang atau memesan melalui platform ojek online di masa pandemi ini. Setelah bingsoo mengganti kemasannya, penjualan pun semakin meningkat dikarenakan konsumen menjadi lebih percaya akan keamanan dari pesanannya. Sekali lagi, pemahaman keinginan dari konsumen yang harus dimengerti oleh pelaku usaha.

Brand, konsumen, media merupakan hal terpenting dalam pemasaran ini. Terlebih lagi disaat krisis, konsumen lah yang akan menjadi penentu lanjut atau tidaknya suatu bisnis. Bisnis yang ditinggalkan konsumennya, cepat atau lambat akan berakhir. Oleh karena itu, strategi bertahan bingsoo lebih pada pendekatan IMC karena IMC merupakan strategi yang berorientasi pada konsumen. Komunikasi yang menjadi hal utama untuk terus menjalin hubungan dengan para konsumen dan juga untuk menarik konsumen baru.

IMC pada penerapannya bisa saja tidak terintegrasi dikarenakan elemen promosi yang digunakan disesuaikan lagi dengan kemampuan perusahaan dengan memperhitungkan budget dan sumber daya manusia (SDM). Dalam hal ini, Bingsoo hanya memiliki 4 orang tim manajemen yang terdiri dari satu owner, dua manajer pemasaran, dan satu admin. Selebihnya adalah karyawan sebanyak 10 orang. Meskipun, bingsoo memiliki sedikit SDM, tetapi bingsoo berhasil bertahan di masa pandemi covid-19 dengan menjalankan beberapa strategi pemasarannya. Terlihat juga bahwa bingsoo berhasil untuk mencapai tujuannya yaitu meningkatkan hasil penjualan.

\section{SIMPULAN}

Strategi bertahan Cafe Bingsoo Malang melalui pendekatan integrated marketing communication di masa pandemi Covid-19 adalah dengan mengkombinasikan beberapa bauran promosi meliputi advertising, social media and website/internet marketing, sales promotion, public relations, personal selling, point of sale and merchandising, corporate identity, packaging, dan word of mouth. Bingsoo berhasil bertahan di masa pandemi Covid-19 dengan mengkombinasikan 9 dari 12 elemen bauran promosi tersebut sehingga dapat menyelamatkan bisnisnya dan meningkatkan hasil penjualannya. Selain itu, hal yang utama adalah kepekaan dalam melihat situasi untuk dijadikan peluang dalam memasarkan produk, terlebih dimasa pandemi ini. Rekomendasi dalam penelitian adalah meningkatkan SDM yang dimilikinya, 
khususnya dalam bagian pemasaran agar strategi yang dijalankan dapat berjalan lebih baik. Kemudian, membuat press release atau sesuatu yang bisa dipublikasikan di media massa atau online sehingga aktivitas promosi khususnya pada bagian hubungan masyarakat dapat diketahui oleh orang banyak. Kemudian lebih peka lagi melihat situasi khususnya tren Korea seperti musik dan dramanya sehingga lebih merealisasikan tagline dari bingsoo yaitu "It's Korean Time".

\section{DAFTAR PUSTAKA}

Amanda, G. (2020). Pengaruh Covid-19 Pada Penurunan Omzet Usaha Mikro. Republika.co.id. Retrieved October 15, 2020

(https://republika.co.id/berita/qc1dlc42 3/pengaruh-covid19-pada-penurunanomzet-usaha- mikro.).

Chrismardani, Y. (2014). Komunikasi Pemasaran Terpadu: Implementasi Untuk UMKM. Neo-Bis 8(2):180-89. doi:https://doi.org/10.21107/nbs.v8i2.4 72.

Damis, M. (2018). Strategi Kebertahanan Usaha Warung Kopi Tikala Manado Suatu Tinjauan Antropologi. Jurnal Holistik 0(0):1-23.

Firmansyah, L. $\mathrm{M}$ and Wulandari, A. R. (2020). Dampak Covid-19 Sejumlah Restoran Akui Peningkatan Pada Layanan Pesan Antar. Lokadata.id. Retrieved October 12, 2020 (https://lokadata.id/artikel/dampakcovid-19-sejumlah-restoran-akuipeningkatan-pada-layanan-pesanantar).

Gunadha, R. and Djailani, M. F. (2020). Tren Pesan Makanan Online Naik Saat Pandemi, Peluang Bagi UMKM. Suara.com. Retrieved October 15, 2020

(https://www.suara.com/bisnis/2020/09

/01/153032/tren-pesan-makananonline-naik-saat-pandemi-peluangbagi-umkm?page=all.).
Hardilawati, W. L. (2020). Strategi Bertahan UMKM Di Tengah Pandemi Covid-19. Jurnal Akuntansi Dan Ekonomika 10(1):89-98. doi: 10.37859/jae.v10i1.1934

Karimah, D. P., Saputra, W. T. and Wahyuningratna, N. (2020). "Implementasi Strategi Komunikasi Pemasaran Pt Dbl Indonesia Pada Honda Dbl Dki Jakarta Series." 3(1):88-99.

https://journal.moestopo.ac.id/index.ph p/pustakom/article/view/990.

Machmud, M. (2018). Tuntutan Penulisan Tugas Akhir Berdasarkan Prinsip Dasar Penelitian Ilmiah. Malang: Selaras.

Morissan, M. A. (2010). Periklanan Komunikasi Pemasaran Terpadu. Jakarta: Kencana.

Pakpahan, A. K. (2020). Covid-19 Dan Implikasi Bagi Usaha Mikro, Kecil, Dan Menengah. Jurnal Ilmiah Hubungan Internasional 0(0):59-64. doi: 10.26593/jihi.v0i0.3870.59-64.

Pasaribu, R. (2020). Optimalisasi Media Online Sebagai Solusi Promosi Pemasaran Umkm Di Semarang Pada Masa Pandemi Covid-19. Jurnal Komunikasi Dan Media 1(1):33. doi: 10.24167/jkm.v1i1.2848.

Prasetyo, B. D., Febriani, N. S., Asmara, W. W., Tamitiadini, D. D., Destrity, N. A., Avina, D. A. A. and Azizun Kurnia Illahi. (2018). Komunikasi Pemasaran Terpadu: Pendekatan Tradisional Hingga Era Media Baru. Malang: UB Press.

Prastyo, D. (2018). "Komunikasi Pemasaran Terpadu Omah Nenek Café Dalam Upaya Meningkatkan Jumlah Konsumen." Universitas 17 Agustus 1945.

Pusparisa, Y. (2020). LIPI: Masyarakat Menonton Drama Korea Lebih Dari Enam Kali Dalam Sepekan. Databoks.katadata.co.id. Retrieved December $\quad 1, \quad 2020$ 
(https://databoks.katadata.co.id/datapu

blish/2020/11/30/lipi-masyarakatmenonton-drama-korea-lebih-darienam-kali-dalam-sepekan.).

Rochim, A. (2020). "Penggunaan Internet Melonjak Di Masa Pandemi Covid-19, Paling Banyak Digunakan Untuk Kirim Pesan." Inews.id. Retrieved October 15 , 2020 (https://www.inews.id/techno/internet/ penggunaan-internet-melonjak-dimasa-pandemi-covid-19-palingbanyak-digunakan-untuk-kirimpesan.).

Santoso, P. Y. (2018). "Transformasi Integrated Marketing Communication Di Era Digital." Jurnal Pustaka Komunikasi 1:313-26.

Septiani, A. (2020). 10 Negara Dengan Kasus Corona Tertinggi Di Asia, Indonesia Urutan Berapa? Health.detik.com.
Retrieved October 31, 2020 (https://health.detik.com/beritadetikhealth/d-5181301/10-negaradengan-kasus-corona-tertinggi-di-asiaindonesia-urutan-berapa.).

Shimp, T. A. (2004). Periklanan Promosi Apek Tambahan Komunikasi Pemasaran Terpadu Edisi 5 Jilid 2. Jakarta: Erlangga.

Smith, P. R., and Ze Zook. (2011). Marketing Communication: Integrating Offline and Online with Social Media. London: Kogan Page.

Susilo, Y. S. (2009). Strategi Bertahan Industri Makanan Skala Kecil Pasca Kenaikan Harga Pangan Dan Energi Di Kota Yogyakarta. Ekuitas 14(110):225-44. doi:

https://doi.org/10.24034/j25485024.y2 010.v14.i2.284. 